\author{
JELENA R. KRULJ ${ }^{1}$ \\ SLAĐANA T. VIDOSAVLJEVIĆ ${ }^{2}$ \\ NATAŠA R. MLADENOVIĆ ${ }^{3}$ \\ UNIVERSITY OF PRIŠTINA IN KOSOVSKA MITROVICA \\ TEACHER EDUCATION FACULTY IN PRIZREN \\ TEMPORARILY SETTLED IN LEPOSAVIĆ
}

\title{
JOHN AMOS COMENIUS - THE TEACHER OF NATIONS AND THE FOUNDER OF DIDACTIC PRINCIPLES
}

\author{
"Not every student has to be an excellent student, \\ but he can become a human being."
}

John Amos Comenius

ABSTRACT. The origin of didactics as a science discipline dates from as far back as the ancient slave states, so the very term didactics (didaskein) comes from the ancient Greek language, meaning to teach. This term later underwent certain changes and the term didactica (didactics) originated in Latin. Today, all scientific vocabulary comes from these two languages (Latin and Greek). The first, more precise definition of this concept was given by Wolfgang Ratke (1571-1635) and John Amos Comenius (1592-1670), who are also considered the founders of didactics. The aim of this paper is to emphasize the importance of didactic principles and the great importance and contribution of Comenius as their founder and the founder of didactics in general. We have to mention that Comenius dedicated his entire life and work to the search for the overall improvement of the teaching process and the education of people, and how successful he was can be seen in the fact

\footnotetext{
jelena.krulj@pr.ac.rs

vidosladja@hotmail.com

natasa.mladenovic@pr.ac.rs
}

This paper was submitted on June $2^{\text {nd }}, 2020$ and accepted for publication at the meeting of the Editorial Board held on September $25^{\text {th }}, 2020$. 
that his didactic principles still stand the test of time. He is considered to be one of the greatest educational reformers.

KEYWORDS: didactics; didactic principles; teaching; education; school.

\section{THE LIFE OF JOHN AMOS COMENIUS}

John Amos Comenius, one of the most influential and famous pedagogues and school reformers, was born on March 28, 1592 in Moravia (Czech Republic) as Jan Szeges. The exact place of birth was not precisely determined, but it is assumed that it is the village of Komna, which is why Comenius was added to his surname, meaning coming from Komna. His family owned a mill, but in his early childhood, at the age of twelve, he was left an orphan. Unfortunately, both of his parents died of plague. He learned to read and write in his mother tongue early on, which made it easier for him to prepare for the job of pastor. However, what always attracted him was education, but he could not continue his education at that point in time. It was not until the age of sixteen that he had the opportunity to do so and he entered the Latin school, which he completed in three years. Comenius finished elementary school, then Latin school and grammar school. After having noticed his intellectual potential, "after a little more than two years, due to his excellent school performance, he was sent by the religious community to the Herborn Academy in Nassau, (a German province at the time) because the University of Prague was not in favour of the 'Czech Brethren"' (Zlebnik, 1962, p. 57). He received his theological education at the Heidelberg University, and as a student he became acquainted with the didactic views of the German pedagogue Ratke and began working on a dictionary of the Czech language.

He returned to his homeland in 1614, and in 1618 he began working as a Protestant pastor and head of the parish school. Comenius devoted himself to reformist and pedagogical work, introduced the teaching of elementary knowledge about nature, wrote a simplified Latin grammar, etc. Moreover, he was chosen as the leader (priest) of a Protestant fraternity, because he "was a member of the Protestant religious group "Czech Brethren", which originated from the left, peasant-plebeian wing of the Hussite movement. He was a teacher and organizer of schools within the religious group to which he belonged. He became a priest and an elder of that group." 
(Коменски, 1997, p. 7). In the same year, 1618, The Thirty Years' War between Catholics and Protestants began in the Czech Republic. After the defeat of Protestant groups in The Battle of White Mountain, he had to move frequently. Enemy soldiers burned his house, and he barely managed to escape with his wife and two small children. Fleeing from Catholic German persecutors, he lost not only his house, property, books and manuscripts, but also his family died of the plague. Constantly persecuted, Comenius hid with the "Czech Brethren" in abandoned huts, caves and forests, and lived as an exile in his own homeland. In 1628, more than 30,000 Czech families left their homeland, including Comenius, who never returned to the Czech Republic. Comenius found in his work the only way out and consolation from such a difficult situation.

He lived and worked in many European countries. He spent some time in Leszno (Poland), where he settled and led a grammar school, and then went to Sweden to Queen Christina's court, and finally to England and Hungary. During that period, he intensively studied pedagogical issues. During his relocations and Northern Wars, some of Comenius' manuscripts were destroyed and disappeared, and he also lost his personal library several times.

In 1631, he published the book Gate of Tongues Unlocked. It was translated into 12 European and 4 Asian languages. In 1632, he completed his main work The Great Didactics (Didactica magna) and wrote it in Czech, and then translated it into Latin - the international literary language. During that period, he gained a world-wide reputation and received invitations from many countries to reorganize their schools. In Hungary, Comenius completed the first-ever illustrated textbook Visible World in Pictures (Orbis sensualium pictus). Thus, Comenius changed and expanded the previous opportunities for the teaching process, so that in addition to listening to the teacher, students could now also visually follow the learning topics. "This book was translated into various languages and has been published numerous times. In addition to the principle of obviousness, this textbook introduces encyclopaedic content and thus real life in school. This textbook is decorated with 302 woodcuts and it was children's favourite reading material for almost two centuries." (Žlebnik, 1962, p. 58)

Comenius returned to Leszno in 1654 , however, the city was destroyed during the war between the Swedes and the Poles and he lost his property for the second time, and found his last refuge in Amsterdam, where all his works were published. Just before his 
death, he opened his heart and described his not so easy life path: "My whole life was a constant journey and I had no homeland. I constantly moved and I was nowhere at home... In the end, the capital of the Netherlands, the market of the world, showed me hospitality" (Марковић, 1990, p. 33). And as the Italian poet Giovanni Rufini (1807-1881) said: "A teacher is like a candle that lights others by consuming itself", so John Amos Comenius, who lived a life full of suffering and creativity, died at the age of 79 .

\section{COMENIUS - THE TEACHER OF NATIONS} AND EDUCATIONAL REFORMER

Teaching, which is the foundation of educational work and a socio-historically conditioned category, is seen as a very old human activity. It also had an important role in the ancient civilizations. It is a planned and organized simultaneous educational process and represents a form of intentional influence on personality development. This would further mean that "teaching is an educational process based on socially determined goals and objectives that are achieved with didactically shaped content, through its various forms and by various means. It is a systematically organized educational process led by a teacher whose task is to help students acquire knowledge, skills and habits and to develop as a person." (Vilotijević, 1999, p. 84). Based on this definition, teaching should effectively use its methods and its contents to contribute to the faster development of personality, and also to the general progress of society. It always implies the unique presence and synergy of three main factors: course content, student and teacher, which form the Didactic Triangle. The European bourgeoisie found the ideologue of such a school and teaching in the Czech pedagogue John Amos Comenius, who is considered the most important reformer in the history of education, because although he was a religious man, he condemned the medieval dogmatism created by the Catholic Church.

Humanism and Renaissance are seen as the cultural revival in all areas of human activity, especially in the field of culture and education. It is believed that "pedagogical realism began and developed rapidly at that time, which the great Czech pedagogue John Amos Comenius accepted and immortalized with his work. He studied 
ancient and medieval pedagogy well and founded modern pedagogy." (Лекић, 2000, p. 54). His enlightenment thought directly influenced the development of pedagogy, but above all the didactics and teaching in general. Russian pedagogue Dzurinski (Джурински, 2000 , p. 130), points out that Comenius is "a humanist who saw the perfect work of nature in every person which enables the development of all its potential, with the role of education being very important as it is supposed to form people who are capable of serving society". When talking about the system of public education, Comenius' demands in this area were very advanced, while his "pedagogical views were influenced by different ideological currents of his time, but the affiliation of the religious group "Czech Brethren" had a threefold significance for the future development of Comenius: religious, socio-philosophical and pedagogical. Its significance for Comenius' pedagogical development was manifested in his fanatical commitment to school work and creative work in pedagogy" (Cenić \& Petrović, 2012, p. 82).

He aspired for democracy in schools and for it to be attended by both genders. Comenius said, "... education is necessary for everyone ... Not the children of the rich or of the powerful only, but of all alike, boys and girls, both noble and ignoble, rich and poor, in all cities and towns, villages and hamlets, should be sent to school." What Comenius also truly fought for was that the mother tongue is used in the classroom, which would primarily facilitate the education of commoner's children, and that "going to school must be mandatory for every child, regardless of financial status and intelligence." He became famous at his time with revolutionary thoughts such as "repetition is the mother of wisdom" and "game-based learning" (Рајчевић, 2014, p. 377). In order to make school and education accessible to all sections of people, he introduced a new way of teaching organization based on the principle of class-subject-lesson school system. He calls the school a "workshop of humanity", a workshop of people. School's task is to teach "all things to all men".

His philosophy is called "pansophism", which means the search for knowledge through encyclopaedic system of human knowledge, because the very meaning of the word pansophia is - omniscience, a comprehensive, versatile human knowledge. The basis of this philosophical thought is the idea that the entire cosmos relies on harmony. He also wrote on the pansophic principles of education, which refer to dividing the entire educational process into four 
periods of six years each. This division is the foundation of the modern school system, and it was conceived in such a way that it foresaw a six-year schooling for each period. Therefore, we have:

1) Childhood, during the first six years of age - Maternal school - the period of physical growth and development of the senses;

2) Boyhood, from six to twelve years of age - School of the mother tongue - it is a period dedicated to the development of memory and imagination;

3) Youth, from the age of twelve to eighteen - Latin school or Grammar school - the main focus is on the ability to comprehend and judge;

4) Maturity - University intended for the most capable students, future scientists. Education ends with a trip abroad.

"With this periodization and educational institutions, Comenius tried to implement his favourite idea of pansophism" (Cenić \& Petrović, 2012). Following the example of humanists and his own pansophism, he sought for this periodization to be used to teach man the knowledge that is of the greatest benefit in human life. In Comenius' opinion, in order for people to be able to adopt pansophism, it was necessary, in addition to opening schools, to improve the teaching itself, which directly and concretely leads to didactics.

\section{DIDACTICA MAGNA}

All of Comenius' works are exceptional pedagogical writings, but the most famous and esteemed work is the Great Didactics (Didactica magna). In this book, he explores how people learn and how they should be educated from their earliest age to university, and further continue with life-long learning. "Didactics is the skill of teaching another person. Recently, some exceptional people, who were tired of Sisyphus' job at school, started researching it with unequal courage and unequal success. We dare to promise great didactics, i.e., a general skill of how to teach everything to everyone. And to teach it reliably, to ensure success at all cost." (Лекић, 2000 , p. 57). As we can see, Comenius defines the notion of didactics as "universal art - teaching everything to everyone", while in his "instruction for teaching" he presents the entire system of education. It is believed that the beginnings of didactics as a science are 
supported by the Great Didactics, which "caused the revolution in education, because it provided a theoretical foundation for the introduction of fundamental innovations in teaching that are considered permanent values, and some of these are: a) school year duration established (the beginning and end of the school year introduced); b) introducing the principle of class-subject-lesson school system; c) request to open teacher education schools and train future teaching staff; $d$ ) introduction of the frontal teaching method which enables the teacher to work with a larger number of students at the same time; e) requirement that teachers and students adhere to obviousness, systematicity, gradualism, repetition, practice, deduction; $\mathrm{f}$ ) although it is necessary, information is not the most important in teaching as it mediates in the intellectual and moral development of students which is the main goal, and is achieved by students thinking independently; g) textbooks should be written in clear language, interconnected and to ensure the gradual flow of learning" (Vilotijević, 1999, pp. 26-27). Comenius believed that schools should come gradually, in stages - from easy to difficult, and that people are born with an inner urge to acquire knowledge. However, in order to eliminate these obstacles, it is necessary to offer more educational possibilities that Comenius defined in his Great Didactics and elaborated in the following topics: 1. Education for everyone, 2. Learning is a natural human tendency, 3. Learning in stages, 4. Financial support, 5. Prepare him/her for the life that is to come, 6. Extracurricular activities, and 7. Lifelong learning.

This laid the foundation for didactic realism as a new pedagogical direction, which dealt a blow to the already unsteady scholastic system of education. As he was strongly influenced by Renaissance humanists, one of whom was the philosopher Francis Bacon, and like him, Comenius based his theory of education on the theory of sensation, which believes that the thought process begins with the senses and that the senses are the basis and source of all knowledge. After analysing these ideas, it can be concluded that "his entire view of the world with elements of materialism, humanism and democracy was formed under the influence of Renaissance humanistic culture and optimistic faith in man - the most excellent creature" (Рајчевић, 2014, p. 381).

of course, in Comenius' Didactics, the main focus is on teaching, both the general facts about it and methodological issues of some subjects. Through these methodological questions, he introduced the method of moral and pious education. What is especially impor- 
tant, not for the development of educational ideas or knowledge of Comenius, but for knowledge of current educational issues, is the fact that many questions can be extracted from his writings and his work, the answers to which must be sought by modern pedagogy and society as a whole, because these are considered the first serious attempts to solve the problems of preschool and school education, as well as an attempt to present future issues in this field. In fact, the Great Didactics represents a detailed pedagogical work that did not omit any significant issues related to man and his education. We can highlight three specific titles: Greetings to the Reader, The Universal Requirements of Teaching and of Learning, and The Principles of Thoroughness in Teaching and in Learning, which present all his pedagogical genius, which is still timeless even now (Коменски, 1997).

\section{FROM THE FIRST ATTEMPTS TO CONSTRUCT THE PRINCIPLE OF OBVIOUSNESS TO THE "GOLDEN RULE" IN TEACHING}

Rules are important for the success of any activity in a person's life, that is, it is necessary to determine and adhere to certain principles every person should live and work by. In some dictionaries, the term principle is explained as the originator, creator, foundation... And this also applies to educational work, for which Comenius was the first to provide certain rules, laws and, of course, principles, which makes him the creator and originator of these. Didactic principles have always been socio-historically conditioned and changed in parallel with the historical development of school and teaching, i.e., they refer to education as a whole and to all stages of education (from preparation to verification). They are derived from the goal and objectives of education, and from the laws of teaching, and they must be in keeping with the psychophysical development of students.

In modern education, these didactic principles have a "multifunctional character compared to the time when they were introduced by Comenius when they served as regulators of the teaching process, because they established general teaching standards (norms); they ensure reciprocal teaching (correlation) and consolidate teaching work into a functional whole (integration)“ (Прода- 
новић, 1968, p. 48). There is no single opinion of didacticians regarding the number and formulation of didactic principles, but they are all unanimous and agree that their influence is particularly important for the course of teaching and a necessary precondition for successful learning. This is understandable, because teaching is not identical everywhere and depends on the social environment in which it happens. Disagreement among didacticians on the understanding and interpretation of the essence and function of certain principles arises from different approaches to this issue and interpretation of relationships between principles and rules, i.e., no clear distinction is made between these two concepts (some converge several principles into one, while others divide one into several different principles). Thus, the number of principles ranges from: 6 (Lekić, 1985), 7 Vilotijević (1999), Андреев (1981), 9 (Јањушевић, 1967), Matijević, Bognar (2002), - up to 35 as elaborated by N. Filipović (1987), noting that this is not the final number either. We agree with Professor Filipovic that the number of principles should not be limited because it would slow down the development of didactic thought and impoverish the theory, but we are of the opinion that they should be reduced to a logical number and those should be chosen that can be applied in the overall organization and implementation of teaching. This means that the selected didactic principles with their essential features should attain their own independence, but also be able to connect with other principles of universality-meaning that they should be applicable in the overall teaching process. Thus, we decided for and singled out these didactic principles: 1 . The principle of scientificity of teaching; 2. The principle of adapting instruction to the age of students; 3. The principle of systematicity and scientificity; 4 . The principle of obviousness; 5 . The principle of conscious student activity; 6 . The principle of individuality; 7. The principle of connecting theory and practice; 8 . The principle of rationality and economy; 9. The principle of permanent knowledge, skills and habits" (Krulj, Kačapor, Kulić, 2003, p. 201), whose meaning and content are not questionable. We have only listed them here, but we have not ranked them by value, because they are all equally important and all are always obligatory and dialectically connected and conditioned.

Comenius is considered to be one of the founders of didactic teaching principles, as we have pointed out before. In our paper, we will list only those principles which he is notable for, and which remain to this day as recognized prerequisites for successful educa- 
tion, and these are: The principle of obviousness, The principle of systematicity and gradualism, and The principle of adapting instruction to the age of students.

\section{THE PRINCIPLE OF OBVIOUSNESS}

Based on the teaching of living in harmony with nature, the principles were created which Comenius recommends as a tool to facilitate teaching, which are: obviousness, gradualism and systematicity. In his opinion, man is a part of nature and is therefore subordinated to its laws. The most general principle, which is the foundation of pedagogy and didactics, is that education should be in harmony with nature and that education must take into account the nature of the child. Comenius was the first who asked for obviousness, relying on knowledge and experience from his many years of school practice. He believed that didactics was a skill of teaching another person, and while studying the teaching methodology (which was applied didactics) he protested against the scholastic school, which relied on verbal teaching and which was considered a 'servant of theology', whose goal was not to find the truth, but to understand and justify the declared truth.

It is well known that medieval philosophy was subordinated to theology and did not deal with the problems of man and life, and any opposition to such teachings was punished mercilessly. Mind is not fed here. Schools teach children to look with other people's eyes, to speak and think with other people's minds. They should be taught to learn about and research things themselves, and not to use other people's observations and testimonies about those things (Коменски, 1954). He demanded that people learn by getting to know things themselves, and not on the basis of others' statements about them. By explaining the importance of sensation in education, he insisted on a comprehensive understanding of objects and phenomena through all the senses, and not only on the basis of the sense of sight, and formulated the "golden rule" of teaching, which required active engagement of all the senses: "Everything visible should be brought before the organ of sight, everything audible before that of hearing. Odours should be placed before the sense of smell, and things that are tastable and tangible before the sense of taste and of touch respectively. If an object can make an impression on several senses at once, it should be brought into contact with several senses" (Коменски, 1954). 
This rule will become the most popular didactic principle during the historical development of teaching, and Comenius explained it with three reasons:

1) The commencement of knowledge must always come from the senses (every understanding is first derived from the senses).

2) The truth and certainty of all knowledge depend more on the witness of the senses than on anything else. This is evident from the fact that belief is at once accorded to knowledge derived from the senses,

3) Knowledge acquired through obviousness (sensuous knowledge) leads to the permanent and better retention of knowledge. Sensuous knowledge is not the only source of knowledge, but only the basic source on the basis of which new knowledge is built with thinking (Коменски, 1954).

As we have already mentioned, Renaissance humanists had the greatest influence on Comenius, and primarily Francis Bacon and his realism, that is, his sensuous philosophy, and the notion that knowledge begins with sensuous perception. The principle of obviousness was set by Comenius as the basis of didactics with an important role in the development of pedagogical theory and school practice. Education relying on obviousness is supposed to enable students to learn the essence of things and the process they are learning about by mentally analysing sensory experiences. "When learning about objects and phenomena, we start from what is concrete, clear and obvious, we rely either on direct perception of objects and phenomena or on manifestations and experiences from earlier observations, and on former knowledge. To apply the principle of obviousness means to follow this path in constructing concepts while guiding children's knowledge." (Теодосић, 1961, p. 202). We must emphasize that obviousness in teaching should ensure the connection between opinion and sensory experiences and cannot be reduced only to observation during class, but from the aspect of modern education it is seen as a requirement that the process of knowledge acquisition is directly or indirectly based on student sensory experiences. Everything that is learned must be proven by the senses and reason. No room should be left for any doubt, nor for the possibility to forget what has been learned... To know an object of study means to know its patterns (Коменски, 1954). It is known from the history of pedagogy that teaching aids were used in Athens: images and models in geometry teaching. 
Even Aristotle pointed out that students should be shown the subject that is being talked about and that is being studied. Comenius explained this principle in his textbook Orbis pictus (1658). He believed that the textbook Visible World in Pictures was a new visual aid for learning: all the important things in the world, all the activities in life were painted and named. It was the teachers' job to discuss it in class with all students. Comenius hoped that the book designed in this way would influence the learning of the young generation. He was of the opinion that learning should be enjoyable, not torment and torture. It is important to focus on the thought that is being enlightened more and more this way. The senses are engaged because in childhood and adolescence abstract things are difficult to grasp. This book is very useful for attracting attention (especially for young people). Students who are interested in such observation of objects will gain the necessary knowledge about important things in the world through jokes and games. Comenius said that children should not be taught wisdom and knowledge from dead books, but from direct observation. This "concept of obviousness of his" is built on the theory of sensation that the senses are the main source of knowledge, that observation and experiments are the basis of science, and induction is the fundamental method" (Krulj, Kačapor, Kulić, 2003, p. 208). The modern concept of obviousness is reflected in the fact that the actual, objective world exists independently of our consciousness and we experience it through the senses with "direct observation". Acquired perceptions reflect the world almost identically and represent a source of knowledge. This implies that students have a clear perception of the outside world in the teaching process, while the path that leads to perception is the use of obviousness in teaching - observation. This principle is one of the most applied, but if it is not adequately applied in teaching, it can have the opposite effect. Namely, it will be a distraction from the important things to the less significant ones, but more prominent in their characteristics. Therefore, this can lead to wrong conclusions and attitudes, so that "the teacher as one of the actors and organizers of teaching process has a great responsibility in choosing and applying teaching principles and methods in certain teaching situations, which is why he/she should know the didactic and methodical application of modern teaching methods" (Видосављевић, 2014, p. 126). Class teacher (subject teacher) is the one who must find the right approach and be a guide through the teaching process. The history of pedagogical and didactic practice 
teaches us that obviousness in teaching, which is used only so as not to be said to be neglected, cannot be considered right, because it is a tool to activate students mentally. Obviousness should be implemented by easily perceived teaching aids, but it is necessary to point out that modern education has such modern audio-visual aids (Internet) that help teachers in the realization of obviousness in teaching and provide students with the perception of those phenomena that were previously considered inaccessible to them, that is, not available for observation.

\section{THE PRINCIPLE OF SYSTEMATICITY AND GRADUALISM}

Comenius was among the first to highlight the need for systematicity in teaching in the $17^{\text {th }}$ century, emphasizing that "everything in teaching is necessarily connected to each other" and observing this through the analogy between nature and education. Systematicity is one of the conditions that ensures the conscious participation of students in the teaching process. The systematic nature of teaching implies: a clear and logical division of teaching materials and the selection of what is important in it: consistent didactic and methodological structuring of the course of the lesson. "The analysis of the learning process shows that without the systematic acquisition of knowledge there are no scientific facts and generalizations, that is, there is no scientific view of the world, because every science has its own systematicity" (Krulj, Kačapor, Kulić, 200, p. 205). In modern school, systematicity is not conditioned only by an appropriate approach to the learning content, but refers to the entire teaching system, to the didactics interpretation of all aspects of the teaching process. "Systematicity refers to presenting content in a certain logical sense, with an isolated stronghold which other content is concentrated around" (Poljak, 1991, p. 42). Therefore, the principle of systematic teaching requires the presentation of new learning material piece by piece, gradually and consistently; formation of knowledge, skills and habits in a certain order, where each element of the teaching material would be logically connected with the following one, which relies on the previous one and leads to new knowledge, to a certain system of logic and creating conditions for the adoption of the system of science. All this means that the prin-

ciple of systematicity (as well as other principles) refers to different aspects of the teaching process. Those aspects are: 
“a) The systematicity requirement primarily refers to the selection and organization of teaching content, which should be taken into account when developing the curriculum for a particular type of school... the subjects and content of these subjects are taken into account, as well as the schedule of presenting the subjects and their content that would enable students to adopt new content with the help of prior, already acquired knowledge.

b) The systematicity requirement also refers to presenting larger or smaller units of teaching content, such as: teaching topics and teaching units. The essence of this request is that the teacher, when planning the lesson, aligns the teaching content with students' abilities, which are directly related to children's prior knowledge.

c) Systematicity also refers to lesson sequencing and procedures used in teaching. The essence of this requirement is that the teacher is mindful that students move on to the adoption of new content only after mastering the old teaching content" (Krulj, Kačapor, Kulić, 2003, p. 206).

The didactic principle of systematicity is concretized to a certain extent in curricula, textbooks, and teaching methods. Systematicity in curricula is just a prerequisite for students to achieve clear and systematic knowledge. The implementation of this principle in everyday teaching and learning is conditioned by the fact that the teacher must constantly monitor the learning process and results of knowledge acquired by students, in order for them to come to know and understand new learning material, and then to expand and deepen their knowledge. Basically, the principle of systematicity is based on teachers' efforts who meet this requirement directly and during the entire teaching process.

Comenius also advocated for gradualism in teaching, because in the process of learning, student should make the distinction between what is important and what is irrelevant, and to independently adopt the facts, laws, and to be able to actively learn. However, students should be introduced with this way of acquiring knowledge gradually, because at the earliest developmental stage and at certain developmental levels, children cannot adopt certain scientific facts. Therefore, these two principles, the principle of systematicity and the principle of gradualness, are connected. He advocated for the teaching material to be taught by connecting its parts to each other, that is, all aspects that are connected should be presented through a cause-and-effect relationship. 
Vladimir Poljak says: "Every complex human activity happens based on a certain system, in a certain order. This also applies to education. There are four rules of gradualness: 1 . from the close to the distant, 2. from the simple to the complex, 3. from the easier to the difficult, 4. from the concrete to the abstract" (Poljak, 1991, p. 43.).

It should be pointed out that gradualness in teaching relies on specific rules that we tie to Diesterweg, and these rules are:

"First rule - from the known to the unknown - is of general importance and Diesterweg says that there is no exception to this rule. The new and the unknown can only be explained with the help of the old and the known, so we should always start from what the students already know... The second rule - from the easier to the difficult - is essentially contained in the previous rule, because in most cases the things students already know are easier for them. According to this rule, the difficulties that students experience should actually increase gradually in line with their knowledge and abilities... The rule - from the simple to the complex - this rule means that in the implementation of the curriculum, teacher should start from simple content and gradually move to the more complex... The rule - from the close to the distant - requires that teaching is based primarily on what is spatially, temporally and mentally closer to the student" (Krulj, Kačapor, Kulić, 2003, p. 207).

When summarizing these rules, it should be emphasized that the principle of gradualness requires that the teaching material is simply taught gradually.

\section{THE PRINCIPLE OF ADAPTING INSTRUCTION TO THE AGE OF STUDENTS}

We have already mentioned in this paper that Comenius was opposed to science being a "servant of theology", even though he himself was very religious. His idea of primary school is incompatible with the feudal ideology, which claimed that the direct producer should not receive any education, and it was to him that Comenius intended primary school. He also noticed the paradox that school, as an institution for educating children and youth, does not take care of the physical and mental abilities of students. It could not have been otherwise, considering that the medieval philosophy did not deal with the problem of man and his life, and any opposition to this was seen as disrespect and was punished. 
"Teaching methods and forms in scholasticism are didactic and methodological combinations of epistemology (science) and theology (religion). No individual interpretation and exploration according to the abilities and age of the students was allowed. "Everything is in God's power, God is one, praise God?!" (Лекић, 2000, p. 63). This tells us that teaching content, teaching methods and procedures, teaching pace and rhythm were not adapted to the students, their abilities and capacities. At that time, school did not even have an exact division into grades, so Comenius was the first to propose a methodological system of teaching by grades, that is, the class-subject-lesson school system. He thus determined that it is very important to specify the age of children when they are psychophysically ready for school. Moreover, he specified the way in which students gradually, step by step, without too much strain and with the gradual development of psyche, move to the next grade that provides them with additional knowledge from given, that is, new subjects. Comenius believed that there should be a "special" book for each grade that would contain the learning material for the given year, and he himself worked a lot on compiling such textbooks. He started from the idea that education should take into account the nature of the child, without overburdening their minds with things, that is, with learning material that does not correspond to their age. In traditional didactics, this principle is called the principle of accessibility (availability): "not to impose on the mind anything that does not correspond to age" (Trnavac \& Đorđević, 2011, p. 202).

Thanks to the new knowledge of anatomy and physiology, and especially knowledge of genetic psychology, we came to a slightly different view of children and young people in general. This knowledge is of great help in the educational system and has also affected the didactic theory and practice. Namely, these findings led to a new formulation of a special didactic principle that teaching should be adapted to the level of development of students' psychophysical abilities. We must emphasize that although the requirement that teaching must be adapted to students' nature is attributed to Comenius, such concepts were also mentioned before. Comenius says not to impose on the mind anything that does not correspond to age, but Diesterweg also said, never teach anything the pupil cannot understand as yet.

We must highlight the fact that, from the historical aspect, there is a number of misconceptions related to the principle of adapta- 
tion of instruction which have been not overcome even today. This means that under the influence of philanthropic pedagogy (philanthropy), this principle is formulated so that the student learns through play and fun, without any effort. Modern didactics does not accept this, because instruction is adapted to the age of students only when the content being taught is neither too difficult nor too easy, but enable the student to master them with appropriate effort. Then, in schools in the past, the only focus was on teaching material, and not on students and their abilities. This is a good thing due to the fact that rigid scientific facts were excluded from the lessons, however, focus on educational content and its structure must not be neglected due to children's nature and psyche. Proper application of this principle, that is, adapted instruction, along with knowledge of children's abilities, actively helps and accelerates their further development.

The principle of adapted instruction is also known as pedocentrism, and this theory places the child at the centre "and everything revolves around it", everything is adapted to it and nothing should be demanded from the child that exceeds the child's abilities and nature of a child. All this means that the pedocentric understanding of the principle of adapted instruction denies social conditioning in education and its social function. We came to the point that we have one extreme, where the student was not taken into account at all, and another extreme, where the student was overestimated and became the main actor in the learning process. Therefore, we can conclude that instruction is tailored to the age of students only when students' abilities are not overestimated or underestimated.

We can conclude that didactic principles are understood as guidelines for teaching activities, i.e., principles from which teaching does not deviate. We have discussed in our paper some of the principles which their creator, their founder, John Amos Comenius is most creditable for. He formulated his famous didactic principles that determine the foundations of school work, which should begin with concrete problems, and not with abstract and theoretical ones. In all these years, the history of pedagogy has proven his thoughts to be accurate and valuable, when he said that everything should be taught in order to trigger changes in life, and that the teacher is obliged to assess students' abilities, and to use them as appropriate. This means that "modern school must imply such an organization of education in which students and teachers, in addi- 
tion to transferring and acquiring knowledge, learn to apply knowledge, communicate successfully with knowledge, implement the acquired knowledge into numerous practical solutions, create new knowledge on the basis of the former one. Knowledge applied in this way is also the main purpose of learning, because without that, knowledge as such is sterile" (Видосављевић, 2014, p. 119). Although teaching principles have been expanded and changed since the origins of didactics, they cannot replace creative work and activity of teachers.

CONCLUSION Education that originated in the very beginnings of human civilization as one of the first forms of human enlightenment, together with teaching that represents one of many types of education and intentional influence on personality development make the world a place where Comenius' pansophism will really come to life through historical and social changes. Comenius actually began his general pedagogical thoughts by determining the goal of education. Teachers' role is to increase students' interest in learning, and that can only be done if they are friendly, kind and loving towards children. This means that each person can learn for themselves, however, instruction without students and teachers as participants in this process makes no sense. The goal of didactics is to help teachers and students in teaching and learning. It is therefore operations science (Meyer, 2002).

In this paper, we have tried to confirm the already known fact that Comenius is one of the most influential personalities in the history of pedagogy (known as Copernicus of pedagogy). The fact is that even now modern pedagogical ideas are explained mainly by his highly democratic and humanistic thought, which he wholeheartedly advocated for and respected in his effort for the enlightenment of people. He remained loyal to these ideals for the rest of his life because he worked tirelessly to propagate the idea that knowledge should be accessible to everyone. It is indisputable that he has great merits as the founder of didactics, and those merits in that area are immeasurable. Enormous creative energy was built into his reformist ideas. Comenius' works are valuable because they cover almost all issues of education. We can group his contribution to pedagogic thought into two large units: reorganization of education and focus on the field of didactics, which includes teaching principles, methods, and textbooks. His greatness lies in the fact that as of today no one has managed to refute his reformist ideas 
and that he is still considered an innovator of education. This reformation that he conducted is mostly related to the fact that Comenius generally looked at science from a practical point of view, that is, he believed that students should learn things that will be useful in life.

As for the organization of instruction and education, he designed in detail the system that is widely used even today, because he defined the indisputable contribution to didactic theory and practical activities in teaching, as follows: 1) he established the beginning and end of the school year; 2) introduced the principle of class-subject-lesson school system; 3) he opened teacher education schools; 4) introduced the frontal teaching method (where teacher works with a larger number of students); 5) required that teachers and students adhere to obviousness, systematicity, gradualism, repetition, practice, deduction; 6) explained the sensation in education and formulated the principles that should be adhered to in working with students, along with a detailed didactic and theoretical guidelines and a unique conceptual meaning; 7) he emphasized the importance of information as an important mediator in the intellectual and moral development of students which is achieved by students thinking independently; 8. emphasized that teachers should help students in a paternal way, with the ability to act and teach in a pedagogical manner, in order for students to successfully learn and mature as people; 9) he insisted that textbooks should be written in clear language, that they should be interconnected and concise."

LITERATURE Cenić, S., Petrović, J. (2012). Vaspitanje kroz istorijske epohe. Vranje: Učiteljski fakultet.

Filipović, N. (1987). Didaktika 1. Sarajevo: „Svjetlost”.

Krulj, S. R., Kačapor, S., Kulić, R. . (2003). Pedagogija. Beograd: Svet knjige.

Lekić, Đ. (1985). Eksperimentalna didaktika (II izdanje). Beograd: Misao

Matijević, M., Bognar, L. (2002). Didaktika. Zagreb: Školska knjiga.

Meyer, H. (2002). Didaktika razredne kvake. Zagreb: Educa.

Poljak, V. (1991). Didaktika. Zagreb: Školska knjiga.

Trnavac, N., Đorđević, J. (2011). Pedagogija. Beograd: Naučna knjiga.

Vilotijević, M. (1999). Didaktika 1 - Predmet didaktike. Beograd: Učiteljski fakultet. 
Žlebnik, L. (1962). Opšta istorija školstva i pedagoških ideja. Beograd: Naučna knjiga.

Андреев, М. (1981). Дияакӣuка. Софија: Државно издатељство „Народна просвета".

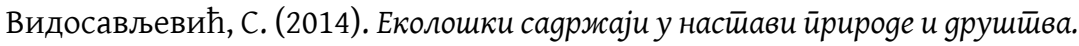
Лепосавић: Учитељски факултет у Призрену - Лепосавићу.

Джуринскии, А. Н. (2000). Пеgaīoīuка: исӣорија йеgaīoīuческих ияеји. Москва: Педагогическое обешство Русија.

Јањушевић,J.М. (1967). Дияакӣuка. Београд: „Вук Караџић"

Коменски, J.A, (1954). Велика gugaкӣuка. Београд: Савез педагошки друштава, Југославија.

Коменски, J. А. (1997). Велика gugaкӣuка. Београд: Завод за уџбенике и наставна средства.

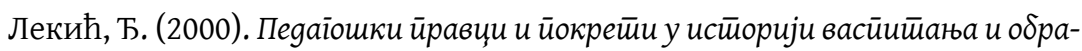
зовања-gойуњено изяање. Београд: Просвета.

Марковић, Н. (1990). Јунац̧и васӣuӣања. Београд: „Вук Караџић”.

Продановић, Т, (1968). Основи gugaкūuке. Београд: Завод за издавање уџठеника СРС.

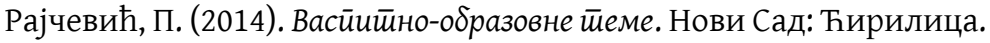

Теодосић, Р. (1961). Пеgаіоіика -уйбеник за Учиеиељске школе. Сарајево: Завод за издавање уџбеника.

ЈЕЛЕНА Р. КРУљ

СЛАЂАНА Т. ВИДОСАВљЕВИЋ

НАТАША Р. МЛАДЕНОВИТ

УНИВЕРЗИТЕТ У ПРИШТИНИ СА ПРИВРЕМЕНИМ СЕДИШТЕМ

У КОСОВСКОЈ МИТРОВИЦИ, УЧИТЕљСКИ ФАКУЛТЕТ У ПРИЗРЕНУ

СА ПРИВРЕМЕНИМ СЕДИШТЕМ У ЛЕПОСАВИЋУ

САЖЕТАК

ЈАН АМОС КОМЕНСКИ - УЧИТЕЉ НАРОДА

И ЗАЧЕТНИК ДИДАКТИЧКИХ ПРИНЦИПА

Порекло дидактике као научне дисциплине сеже у дубоку прошлост древних робовласничких држава, па тако и сам термин дидактика (didaskein) потиче из старогрчког језика, што би у преводу значило обучавати. Термин је касније претрпео извесне промене и управо термин didactica (дидактика) настаје у латинском језику. Оठа ова језика (грчки и латински) чине данас осно- 
ву целокупне научне терминологије. Прво и прецизније дефинисање овог појма дали су Волфганг Ратке (1571-1635) и Јан Амос Коменски (1592-1670), који се сматрају и оснивачима дидактике. Овај рад има за циљ да укаже на важност дидактичких принципа и на велик значај и допринос Коменског као њиховог оснивача и оснивача дидактике уопште. Морамо напоменути да је Коменски цео свој живот и рад посветио трагању за свеукупним унапређењем наставног процеса и образовању народа, а колико је у томе успео може се препознати у томе да његови дидактички принципи и данас одолевају времену. Сматра се да је он један од највећих реформатора школства.

КљУчНЕ РЕчи: дидактика; дидактички принципи; настава; образовање; школа.

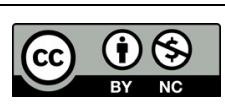

Овај чланак је објављен и дистрибуира се под лиценцом Creative Commons Ауторство-Некомерцијално Међународна 4.0 (CC BY-NC 4.0 |

https://creativecommons.org/licenses/by-nc/4.0/).

This paper is published and distributed under the terms and conditions of the Creative Commons Attribution-NonCommercial International 4.0 licence (CC BY-NC 4.0 | https://creativecommons.org/licenses/by-nc/4.0/). 